\title{
Comparative study of synthesized silver and gold nanoparticles using leaves extract of Bauhinia tomentosa Linn and their anticancer efficacy
}

\author{
D MUKUNDAN ${ }^{1, *}$, R MOHANKUMAR $^{2}$ and R VASANTHAKUMARI ${ }^{1}$ \\ ${ }^{1}$ Polymer Nano Technology Centre, B S A Crescent University, Chennai 600 048, India \\ ${ }^{2}$ Interdisciplinary Institute of Indian System of Medicine, SRM University, Kattankulathur, Chennai 603203, India
}

MS received 20 April 2016; accepted 2 July 2016

\begin{abstract}
Nanotechnology is an emerging field in science and technology, which can be applied to synthesize new materials at the nanoscale level. The present investigation aimed at comparing the synthesis, characterization and in vitro anticancer efficacy of synthesized silver and gold nanoparticles using leaves extract of Bauhinia tomentosa Linn. Silver nanoparticles (AgNPs) and gold nanoparticles (AuNPs) were synthesized using aqueous extract of leaves with solution of silver nitrate $\left(\mathrm{AgNO}_{3}, 1 \mathrm{mM}\right)$ and chloroauric acid $\left(\mathrm{HAuCl}_{4} \cdot 3 \mathrm{H}_{2} \mathrm{O}, 1 \mathrm{mM}\right)$, respectively. The synthesized nanoparticles were characterized using UV-visible spectrophotometry, Fourier transform infrared spectroscopy, field emission scanning electron microscopy, high-resolution transmission electron microscopy, energy-dispersive analysis of X-rays, X-ray diffraction, thermogravimetric analysis and cyclic voltammetry, which confirmed the reduction of $\mathrm{Ag}^{+}$ions to $\mathrm{Ag}^{0}$ and $\mathrm{Au}^{3+}$ ions to $\mathrm{Au}^{0}$. The in vitro anticancer efficacy of $\mathrm{AgNPs}^{3}$ AuNPs and aqueous extract of leaves confirmed by MTT assay exhibited $\mathrm{IC}_{50}$ concentrations of 28.125, 46.875 and $50 \mu \mathrm{g} \mathrm{ml}^{-1}$ for lung A-549 cells, 103.125, 34.375 and 53.125 $\mu \mathrm{g} \mathrm{ml}^{-1}$ for HEp-2 cells and 62.5, 23.4 and 13.26 $\mu \mathrm{g} \mathrm{ml}^{-1}$ for MCF-7 cells, respectively. The concentrations indicate that both silver and gold nanoparticles as well as aqueous extract of leaves exhibited high anticancer efficacy.
\end{abstract}

Keywords. Bauhinia tomentosa Linn; silver nanoparticles; gold nanoparticles; A-549; HEp-2; MCF-7.

\section{Introduction}

Metal nanoparticles, ranging from colloidal solutions to organometallic clusters, have been widely investigated since the path-breaking studies of colloidal gold by Faraday [1]. Metal nanoparticles have found an increased interest due to their variation in optical, magnetic and electrical properties as they are dependent on their size, surface plasmon, surface free energy and surface area. Hence, the size-dependent properties of metal nanoparticles have been exploited in technological applications ranging from electronics [2,3], optics [4] and sensing [5-7] to catalysis [8].

Different types of nanomaterials like copper, zinc, titanium [9], magnesium, gold [10], alginate [11] and silver have been synthesized but silver nanoparticles have proved to be the most effective due to their high antimicrobial efficacy against bacteria, viruses and other eukaryotic microorganisms [12]. Of the different nanomaterials synthesized, silver nanoparticles play a major role in the field of nanotechnology and nanomedicine. Colloidal silver is of particular interest due to its distinctive properties like good conductivity, chemical stability and catalytic and antibacterial activities [13]. Similarly, gold nanoparticles, due to their chemical inertness and biocompatibility, have been found suitable for biomedical applications such as the treatment of cancer, gene therapy and drug delivery systems $[14,15]$.

\footnotetext{
*Author for correspondence (mukundraj85@gmail.com)
}

Earlier, intracellular and extracellular synthesis of nanoparticles was carried out using microbes, which required aseptic conditions and longer time [16]. Biosynthesis of nanoparticles using plants is an exciting possibility as it takes less time for the synthesis [17,18]. A number of plants have been exploited for nanoparticle synthesis [19-24] and many plants are yet to be explored. Nanoparticle size and shape depend on the phytochemical constituents of plants, temperature required for the reaction and extract composition [25].

Bauhinia tomentosa, known as yellow bell orchid tree in vernacular terms, belongs to Fabaceae family and is one of the best versatile plants, most commonly used as a household remedy for curing many diseases. The generic name refers to the Bauhin brothers Jean and Gaspard, Swiss botanists, with the two lobes of the leaf exemplifying the two brothers. The species name 'tomentosa' means hairy and refers to the velvety/hairy pods. This plant is found along the coastal strip from Southern Kwazulu-Natal to Maputo land, Mpumalanga, Mozambique, Zimbabwe, Tropical Africa, India and Srilanka. It is also found in the plain southwards of Delhi in the peninsular region, West Bengal. The leaves of $B$. tomentosa contain phytoconstituents like kaempferol-7-0-rhamnoside, kaempferol-3-0-glucoside, quercitin-3-0-glucoside and quercitin-3-0-rutinoside [26]. The cytotoxic and antioxidant activity exhibited by the leaves and the anti-hyperglycemic and antilipidemic activity exhibited by the flowers were reported in [27]. Pharmacognostical and phytochemical screening of $B$. tomentosa Linn leaves 
was reported in [28]. Qualitative phytochemical analysis and DPPH scavenging activity of aqueous extract of leaves of $B$. tomentosa Linn have been reported [29,30].

Although the applications of plant parts of $B$. tomentosa Linn have been analysed to a certain extent, the synthesis of metal nanoparticles using leaf extract of plants, the properties of the synthesized nanoparticles and their in vitro anticancer activity on different cell lines have not been explored. The present investigation aimed at comparing the synthesis, spectroscopic, morphological, chemical, structural, thermal and electrochemical characterization and in vitro anticancer efficacy of silver and gold nanoparticles synthesized using leaves extract of $B$. tomentosa Linn.

\section{Materials}

Leaves of $B$. tomentosa Linn were collected in and around from Chennai and authenticated by Dr S Jayaraman, Director of Plant and Anatomy Research Centre, Chennai (Registration Number PARC/2013/2189). Aqueous extract of leaves of B. tomentosa was prepared following the procedure of [30].

Silver nitrate $\left(\mathrm{AgNO}_{3}\right)(99.99 \%)$, chloroauric acid $\left(\mathrm{HAuCl}_{4}\right.$. $\left.3 \mathrm{H}_{2} \mathrm{O}\right)(99.99 \%)$, minimal essential media, fetal bovine serum, trypsin, streptomycin, 3-(4, 5-dimethyl-2-thiazolyl)2, 5-diphenyl-tetrazolium bromide (MTT) and dimethyl sulphoxide were procured from $\mathrm{Hi}$ Media and Sigma Aldrich, Mumbai.

Vero (Cercopithecus aethiops kidney epithelial normal), A-549 (human lung adenocarcinoma epithelial), HEp-2 (human laryngeal epithelial carcinoma) and MCF-7 (human breast adenocarcinoma) cell lines were obtained from National Centre for Cell Sciences (NCCS), Pune, India.

\section{Synthesis of silver and gold nanoparticles}

Silver and gold nanoparticles were synthesized by adding $5 \mathrm{ml}$ of aqueous extract of $B$. tomentosa leaves to $95 \mathrm{ml}$ of $1 \mathrm{mM}$ aqueous $\mathrm{AgNO}_{3}$ solution and $95 \mathrm{ml}$ of $1 \mathrm{mM}$ aqueous $\mathrm{HAuCl}_{4} \cdot 3 \mathrm{H}_{2} \mathrm{O}$ solution at room temperature, respectively. The change in colour of the solution from pale yellow to reddish brown and pale yellow to ruby red indicated the reduction of $\mathrm{Ag}^{+}$ions to $\mathrm{Ag}^{0}$ and $\mathrm{Au}^{3+}$ ions to $\mathrm{Au}^{0}$, respectively. The formation of reddish brown and ruby red solution established the preliminary confirmation for the formation of plant-extract-mediated synthesis of silver and gold nanoparticles, respectively [31]. Silver and gold nanoparticles were obtained by centrifuging the solution at $5000 \mathrm{rpm}$ for $20 \mathrm{~min}$ followed by repeated washing with water three times and the lyophilized powder was stored for characterization.

\section{Characterization of synthesized silver and gold nanoparticles}

The spectral response of synthesized AgNPs and AuNPs was studied using a UV-visible spectrophotometer (Thermo
Scientific-Evolution 201). Fourier transform infrared spectroscopy (FTIR) results were obtained from a Jasco 6300 spectrometer (ATR mode) in the range of $400-4000 \mathrm{~cm}^{-1}$. The surface morphology and shape of the nanoparticles were examined using field emission scanning electron microscopy (FESEM; Hitachi SU6600, Japan) and high-resolution transmission electron microscopy (HR-TEM; Tecnai T-30 $\mathrm{G}^{2}$, D-905), respectively. The chemical composition of the nanoparticles was examined using energy-dispersive analysis of X-rays (EDAX; EMAX, Horiba 8121-H, Japan). Powder X-ray diffraction (XRD; Rigaku, Miniflex-600, Japan) was performed using an X-ray diffractometer- $\mathrm{Cu} \mathrm{K} \alpha$ radiation system to determine the structure of synthesized nanoparticles. Thermogravimetric analysis (TGA) of the plant powder and synthesized nanoparticles was done on Seiko Instruments TG/DTA6200 EXSTAR 6000 in a $140 \mathrm{ml} \mathrm{min}^{-1}$

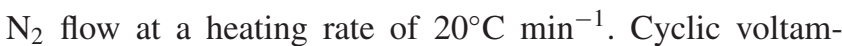
metry was carried out using an electrochemical analyser (CHI760C) to study the oxidation state of metal ions in a potential range of -2 to $2 \mathrm{~V}$. Calomel $\left(\mathrm{Hg} / \mathrm{Hg}_{2} \mathrm{Cl}_{2}\right)$, glassy carbon and platinum wire served as reference, working and counter electrodes, respectively.

\section{In vitro anticancer activity of silver, gold nanoparticles and aqueous extract of leaves}

The in vitro anticancer activities of the synthesized silver, gold nanoparticles and aqueous extract of leaves on Vero, A-549, HEp-2 and MCF-7 cancer cells were determined by MTT assay (Mosmann 1983) [32]. The concentration of nanoparticles and aqueous extract of leaves required for $50 \%$ inhibition of viability $\left(\mathrm{IC}_{50}\right)$ was determined graphically. The anticancer effect of nanoparticles and aqueous extract of leaves on the proliferation of cancer cells was expressed as percentage cell viability from the formula

Percentage $(\%)$ cell viability $=$ (absorbance of treated cells at $540 \mathrm{~nm} /$ absorbance of control cells at $540 \mathrm{~nm}) \times 100$.

In addition, the morphological changes of A-549, HEp-2 and MCF-7 cells treated with silver and gold nanoparticles were visualized using an inverted microscope at $40 x$ magnification (Labomed).

\section{Results and discussion}

\subsection{Spectroscopic characterization}

6.1a UV-visible spectroscopy: UV-visible spectrum of the synthesized silver and gold nanoparticles is shown in figure 1. The surface plasmon resonance (SPR) for the synthesized silver nanoparticles occurred at $441 \mathrm{~nm}$, while the SPR for gold nanoparticles occurred at $563 \mathrm{~nm}$. Similarly, UV-visible spectrum of AgNPs and AuNPs has been reported using Azadirachta indica leaf broth [22]. 


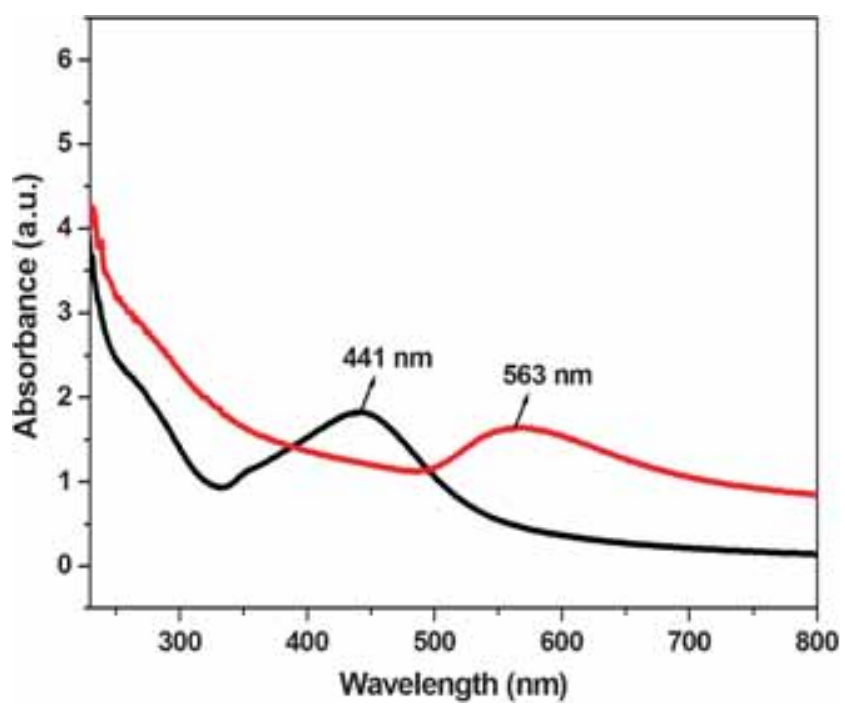

Figure 1. UV-visible spectrum of synthesized silver and gold nanoparticles.

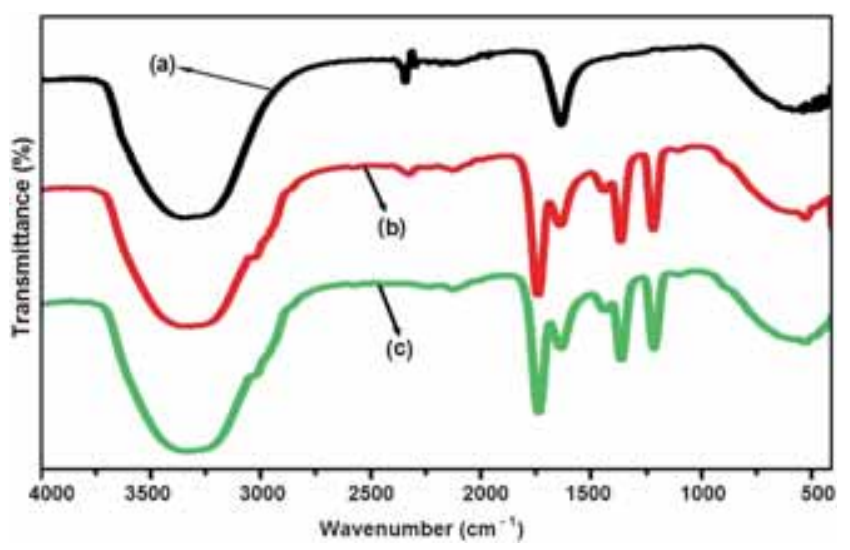

Figure 2. FTIR spectrum of (a) B. tomentosa leaves extract, (b) AuNP and (c) AgNP.

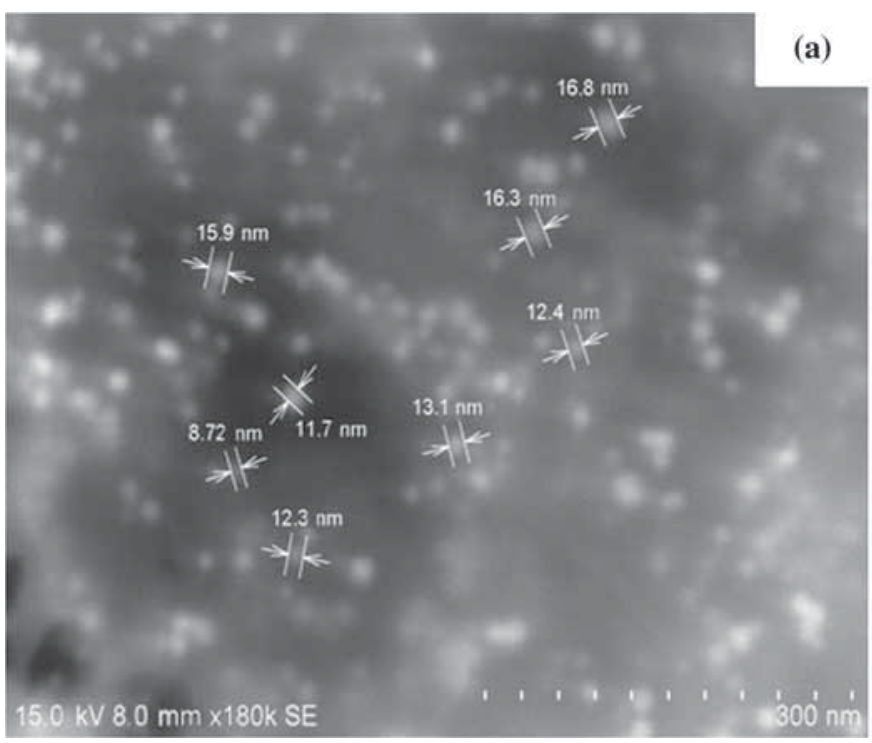

(a)

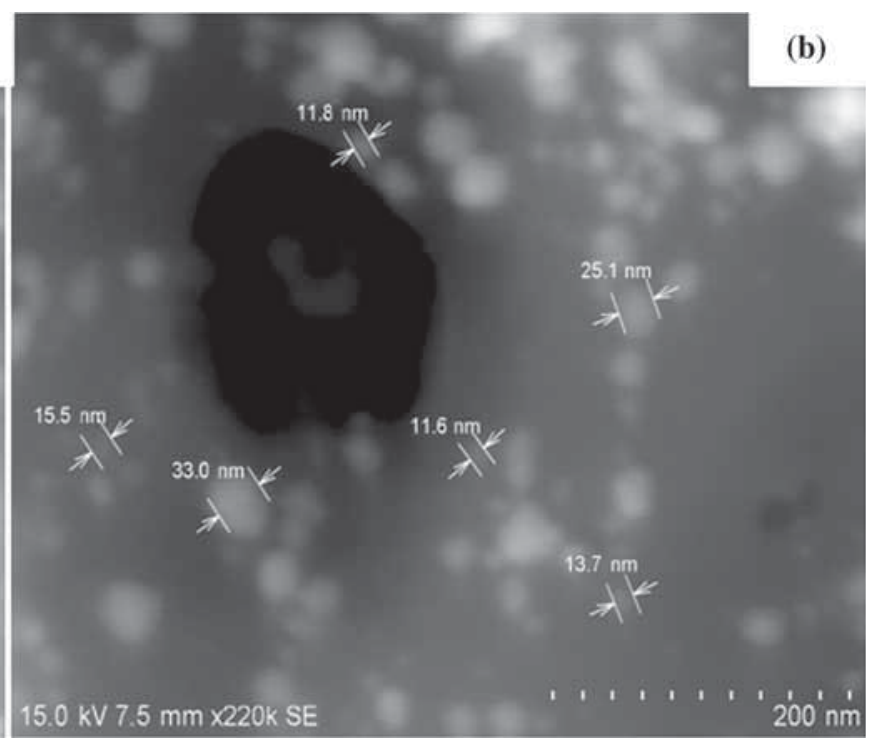

6.1b FTIR: FTIR spectrum of B. tomentosa leaf extract, after synthesis of AuNP and AgNP, is shown in figure $2 \mathrm{a}-\mathrm{c}$. The leaf extract shows characteristic vibrational peaks at 3340, 2343, 2300, 1635 and $539 \mathrm{~cm}^{-1}$, which correspond to functional groups $\mathrm{OH}$ (broad stretching), $\mathrm{P}-\mathrm{H}$ (strong), $\mathrm{NH}$ (strong bending) and disulphide (S-S, weak), respectively. Characteristic vibrations after reduction of $\mathrm{Ag}^{+}$ions and $\mathrm{Au}^{3+}$ ions by $B$. tomentosa leaves extract were found to be $3340,2130,1737,1637,1438,1365,1218,1103,528$ and $3342,2323,2125,1737,1639,1436,1365,1218$ and $526 \mathrm{~cm}^{-1}$, respectively. Figure $2 \mathrm{~b}$ and $\mathrm{c}$ shows vibrations attributed to functional groups such as alcohols and phenols (broad $\mathrm{O}-\mathrm{H}$ stretching), alkynes $(\mathrm{C} \equiv \mathrm{C})$, saturated aldehydes (strong $\mathrm{C}=\mathrm{O}$ bending), primary and secondary amines or amides (weak $\mathrm{NH}_{2}$ bending), alkanes (medium $\mathrm{CH}_{2}$ and $\mathrm{CH}_{3}$ deformation bending), carboxylic acid derivatives (medium $\mathrm{O}-\mathrm{C}$ bending) and disulphide (weak $\mathrm{S}-\mathrm{S}$ bending) confirmed that the phytoconstituents present in the leaves extract were responsible for the reduction of silver and gold ions to silver and gold nanoparticles. Similarly, FTIR spectra after reduction of $\mathrm{Ag}^{+}$ions and $\mathrm{Au}^{3+}$ ions by plant leaves have been reported $[22,33]$.

\subsection{Morphological characterization}

6.2a FESEM: FESEM analysis of synthesized AgNPs and AuNPs are shown in figure $3 a$ and $b$, respectively. AgNPs showed the presence of polydispersed spherical particles and the particle size ranged from 8.72 to $33 \mathrm{~nm}$. Similarly, synthesized AuNPs showed the presence of polydispersed spherical nanoparticles with the particle size ranging from 11.5 to $40 \mathrm{~nm}$. The average particle size of the synthesized AgNPs and AuNPs was found to be 18.45 and $27.8 \mathrm{~nm}$, respectively. Similarly, the presence of spherical silver nanoparticles using Glycyrrhiza glabra root extract and the presence of spherical gold nanoparticles using Pistia stratiotes L. has been reported by [34] and [35], respectively.

Figure 3. FESEM of (a) Ag and (b) Au nanoparticles. 


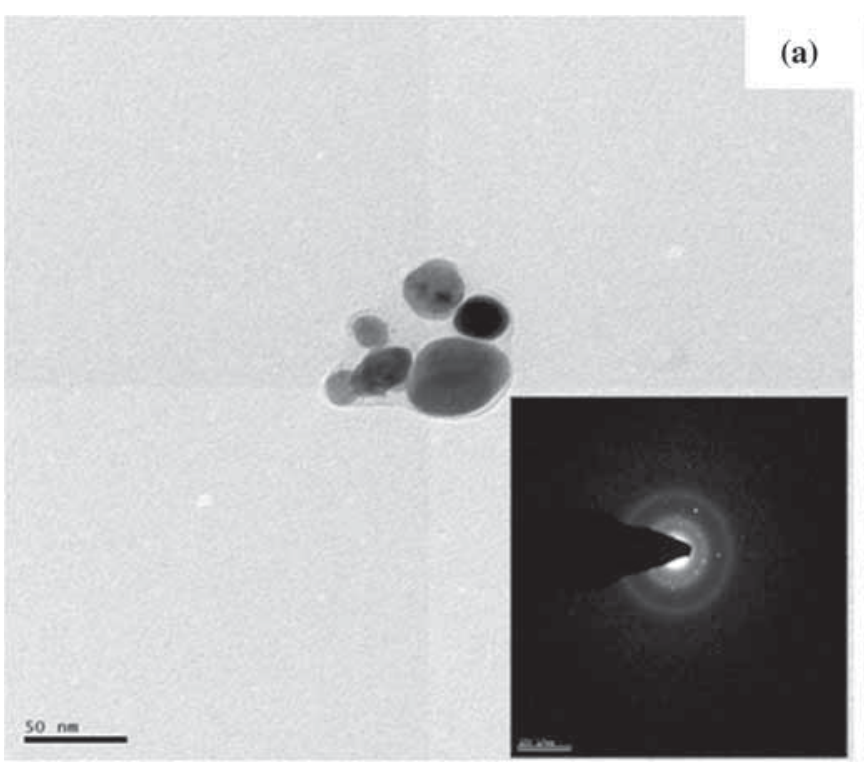

Figure 4. HR-TEM of synthesized (a) Ag and (b) Au nanoparticles.

Table 1. EDAX of AgNP and AuNP.

\begin{tabular}{lcc}
\hline Elements & EDAX of AgNP (wt\%) & EDAX of AuNP (wt\%) \\
\hline Silver (Ag) & 19.50 & - \\
Gold (Au) & - & 64.14 \\
Oxygen (O) & 75.05 & 35.86 \\
Carbon (C) & 5.44 & - \\
\hline
\end{tabular}

6.2b HR-TEM: HR-TEM images of silver and gold nanoparticles synthesized using aqueous extract of $B$. tomentosa leaves are shown in figure $4 \mathrm{a}$ and $\mathrm{b}$, respectively. The synthesized silver and gold nanoparticles were of spherical or near-spherical shape and polydispersed with an average diameter of 16.73 and $31.32 \mathrm{~nm}$, respectively. Both AgNPs and AuNPs were found to be encapsulated by organic biomolecules present in the leaves extract. Singh et al [33] reported a similar geometry of synthesized silver and gold nanoparticles using natural precursor clove. Selected area electron diffraction (SAED) patterns for silver and gold nanoparticles are shown in figure $4 \mathrm{a}$ (inset) and b (inset), respectively. The ring-like pattern with bright circular spots corresponding to Bragg's planes confirmed the polycrystalline structure of silver and gold nanoparticles.

\subsection{Chemical characterization}

6.3a Energy dispersive X-rays: EDAX of synthesized silver and gold nanoparticles is shown in table 1 . The chemical compositions of $\mathrm{Ag}$ and $\mathrm{Au}$ were 19.50 and $64.14 \mathrm{wt} \%$, respectively. EDAX spectrum of $\mathrm{Ag}$ and $\mathrm{Au}$ nanoparticles is shown in figure $5 \mathrm{a}$ and $\mathrm{b}$, respectively. The spectrum confirmed the presence of a strong peak for elemental silver at approximately $3 \mathrm{keV}$ and the presence of a strong absorption peak for elemental gold at approximately $2 \mathrm{keV}$. The oxygen and carbon peaks might be due

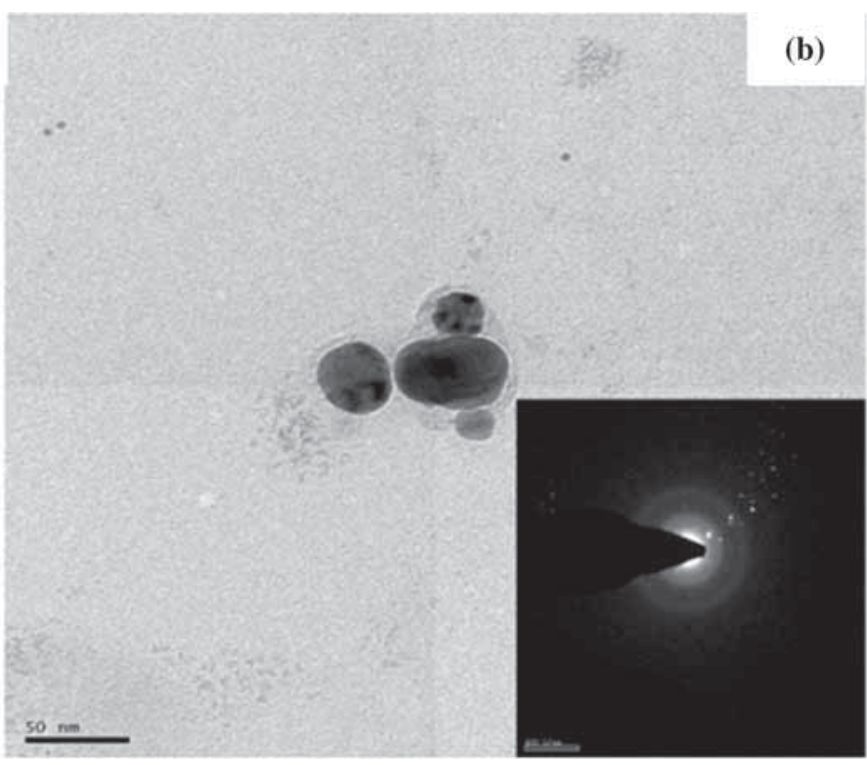

to the presence of biomolecules bound to the surface of the synthesized nanoparticles. Dinesh et al [34] confirmed the presence of a silver peak using G. glabra root extract and Anuradha et al [35] confirmed the presence of a gold peak using $P$. stratiotes $\mathrm{L}$.

\subsection{Structural characterization}

6.4a XRD: The XRD pattern of synthesized AgNPs and AuNPs is shown in figure 6. The XRD patterns at 38.250, $44.29,64.54,77.45$ and 81.65 corresponding to the lattice planes [(111), (200), (220), (311), (222)] and 38.04, $44.12,64.52,77.49$ and 81.53 corresponding to the lattice planes [(111), (200), (220), (311), (222)] are in accordance with the reported pattern (JCPDS 04-0783) and (JCPDS 040784), which confirmed that the green synthesized AgNPs and AuNPs are nanocrystalline with fcc crystal structure, respectively. A similar pattern of XRD for silver and gold nanoparticles has been reported by Shankar et al [22]. Table 2 depicts the $d$-spacing, full-width at half-maximum (FWHM), $(h k l)$ lattice planes, lattice parameter and particle size of the synthesized silver and gold nanoparticles. The average particle size of silver and gold nanoparticles was determined to be 15.672 and $15.236 \mathrm{~nm}$, respectively.

\subsection{Thermal characterization}

6.5a TGA: The thermal stabilities of $B$. tomentosa leaves powder and synthesized silver and gold nanoparticles are shown in figure $7 \mathrm{a}-\mathrm{c}$. The TGA plot shows a two-step decomposition of the leaf powder. The first step from 30 to $300^{\circ} \mathrm{C}$ is due to the decomposition of bio-organic molecules present in the leaf powder. The second step from 300 to $500^{\circ} \mathrm{C}$ shows that the leaf powder undergoes complete decomposition at $500^{\circ} \mathrm{C}$. The TGA plot of the synthesized silver nanoparticles shows a two-step decomposition curve 

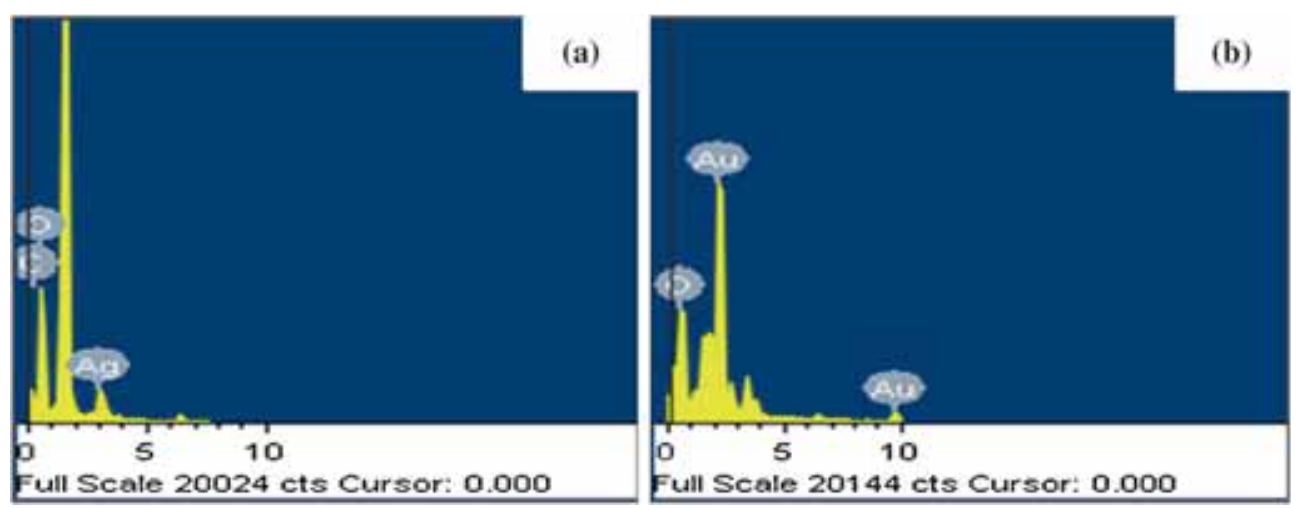

Figure 5. EDAX spectrum of synthesized (a) Ag and (b) Au nanoparticles.

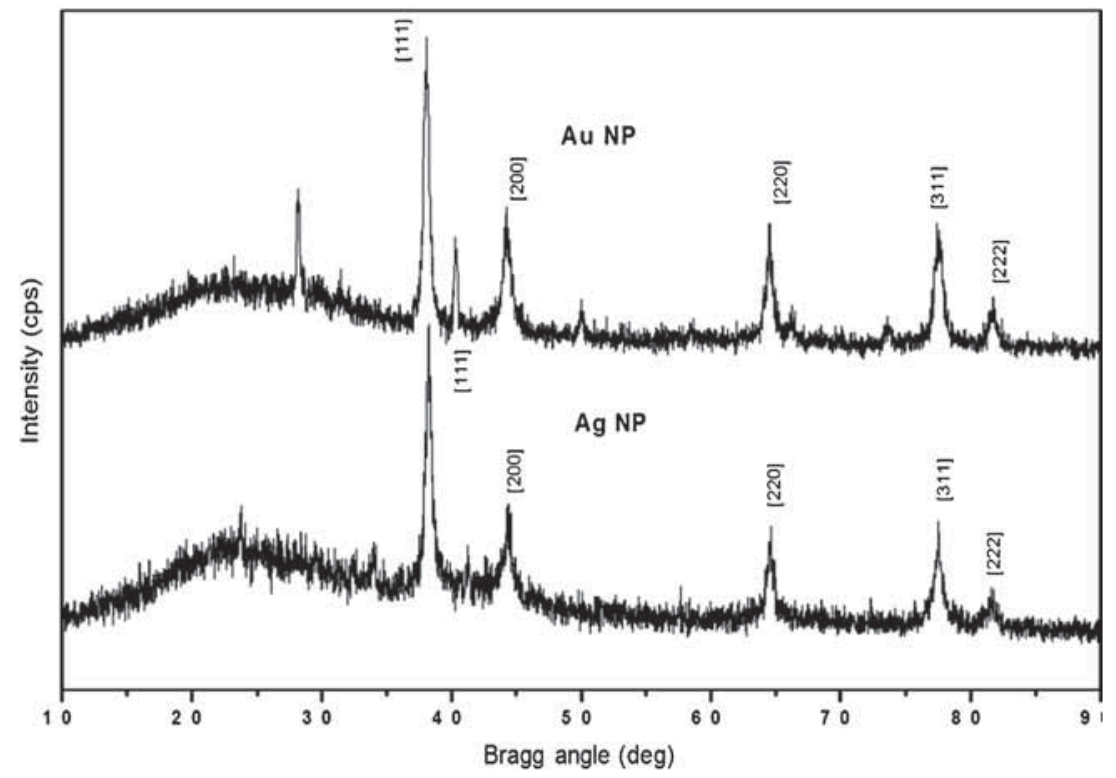

Figure 6. XRD pattern of synthesized AgNP and AuNP.

Table 2. Size of synthesized silver and gold nanoparticles.

\begin{tabular}{lcccccc}
\hline Nanoparticle & $\begin{array}{c}\text { Intense peak } \\
2 \theta(\mathrm{deg})\end{array}$ & $\begin{array}{c}d \text {-spacing } \\
(\mathrm{nm})\end{array}$ & $\begin{array}{c}\text { Intense peak } \\
\text { FWHM, } \beta(\mathrm{deg})\end{array}$ & $\begin{array}{c}\text { Lattice plane } \\
(h k l)\end{array}$ & $\begin{array}{c}\text { Lattice } \\
\text { parameter }(\AA)\end{array}$ & $\begin{array}{c}\text { Size of } \\
\text { nanoparticle }(\mathrm{nm})\end{array}$ \\
\hline Silver $(\mathrm{Ag})$ & 38.250 & 0.23511 & 0.48 & $(111)$ & 4.072 & 18.3 \\
& 44.29 & 0.20433 & 0.75 & $(200)$ & 4.086 & 11.95 \\
& 64.55 & 0.14425 & 0.53 & $(220)$ & 4.080 & 18.52 \\
& 77.45 & 0.12313 & 0.72 & $(311)$ & 4.083 & 14.77 \\
Gold $(\mathrm{Au})$ & 81.66 & 0.11782 & 0.74 & $(222)$ & 4.081 & 14.82 \\
& 38.040 & 0.23636 & 0.532 & $(111)$ & 4.093 & 16.5 \\
& 44.123 & 0.20508 & 0.76 & $(200)$ & 4.101 & 11.78 \\
& 64.526 & 0.14430 & 0.58 & $(220)$ & 4.081 & 16.92 \\
& 77.49 & 0.12307 & 0.74 & $(311)$ & 4.081 & 14.38 \\
\hline
\end{tabular}

from 30 to 150 and 150 to $325^{\circ} \mathrm{C}$, which is due to the evaporation of water present on the surface of AgNPs and removal of organic biomolecules encapsulating the silver nanoparticles, respectively. Above 325 to $800^{\circ} \mathrm{C}$ there was no decomposition, indicating that the residue accounted for metallic silver. The analysis for AgNPs showed that the starting material weighed $2.353 \mathrm{mg}$ and the total loss of organic matter was $1.545 \mathrm{mg}(65.66 \%)$. The TGA plot of the 
synthesized gold nanoparticles depicts a two-step decomposition curve from 30 to 120 and 120 to $300^{\circ} \mathrm{C}$ for evaporation of water present on the surface of AuNPs and removal of bioorganic compounds encapsulating the gold nanoparticles,

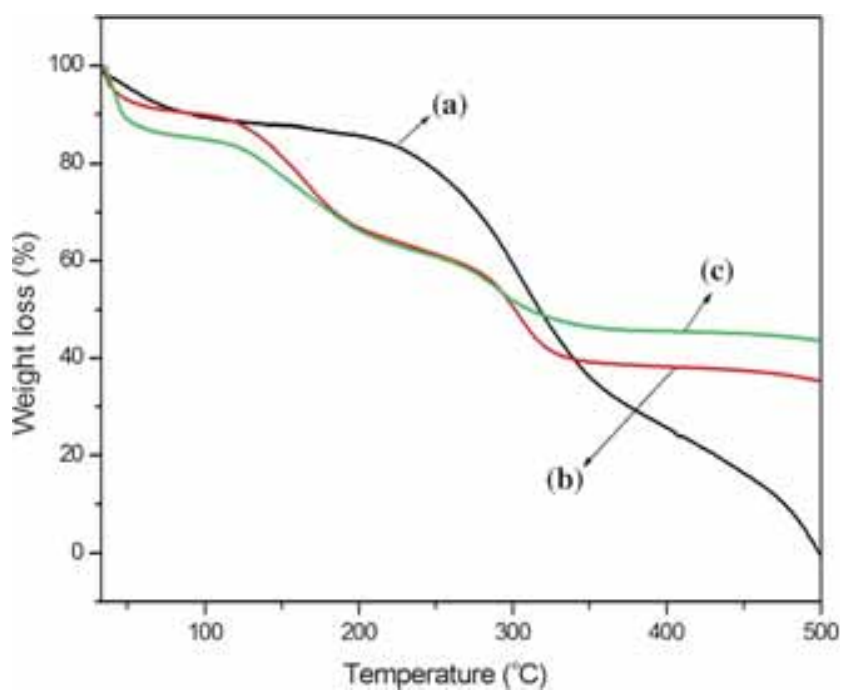

Figure 7. Thermal gravimetric analysis of (a) B. tomentosa leaves powder, (b) AgNP and (c) AuNP.

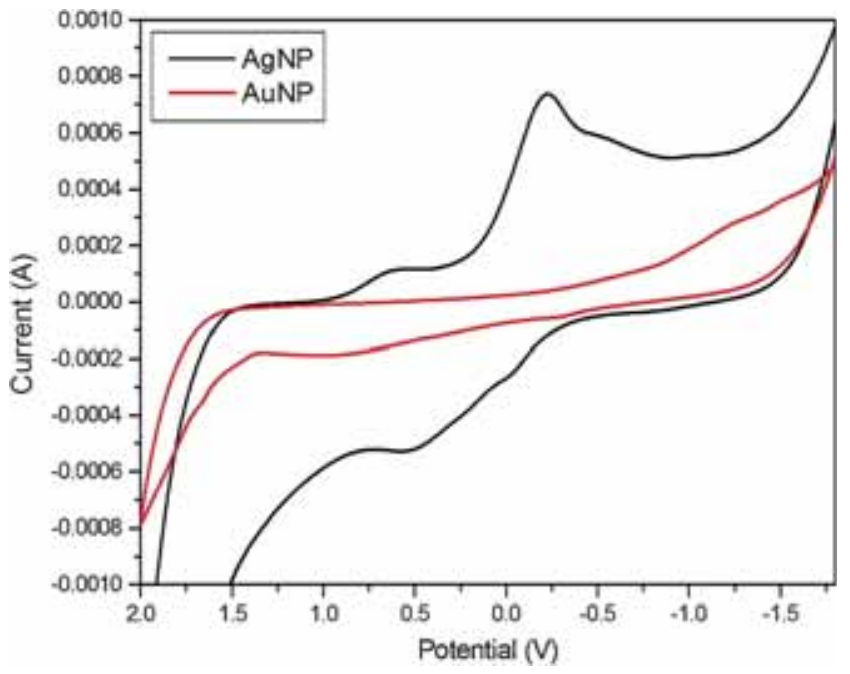

Figure 8. Cyclic voltammogram of AgNP and AuNP.

Table 3. $\mathrm{IC}_{50}$ of Vero, A-549, HEp-2 and MCF-7 cells treated with silver and gold nanoparticles and aqueous extract of leaves of B. tomentosa.

\begin{tabular}{lccc}
\hline $\begin{array}{c}\mathrm{IC}_{50} \text { of cells } \\
\text { treated with } \\
\mathrm{AgNP}\left(\mu \mathrm{g} \mathrm{ml}^{-1}\right)\end{array}$ & $\begin{array}{c}\mathrm{IC}_{50} \text { of cells } \\
\text { treated with } \\
\mathrm{AuNP}\left(\mu \mathrm{g} \mathrm{ml}^{-1}\right)\end{array}$ & $\begin{array}{c}\mathrm{IC}_{50} \text { of cells treated } \\
\text { with aqueous extract } \\
\text { of leaves }\left(\mu \mathrm{g} \mathrm{ml}^{-1}\right)\end{array}$ \\
\hline Vero & 425.0 & 212.5 & 700.0 \\
A-549 & 28.125 & 46.875 & 50.0 \\
HEp-2 & 103.125 & 34.375 & 53.125 \\
MCF-7 & 62.5 & 23.4 & 13.26 \\
\hline
\end{tabular}

respectively. Above 300 to $800^{\circ} \mathrm{C}$ there was no decomposition, indicating that the residue accounted for metallic gold. The analysis for AuNPs showed that the powder weighed $4.108 \mathrm{mg}$ initially and the total loss of organic matter was $2.352 \mathrm{mg}(57.25 \%)$. Similarly Mittal et al [36] and Ismail et al [37] reported TGA analysis of AgNPs synthesized using flower extract of Rhododendron dauricum and AuNPs using extract of Vitis vinifera leaves and seeds, respectively.

\subsection{Electrochemical analysis}

6.6a Cyclic voltammetry: Figure 8 depicts the cyclic votammogram of synthesized AgNPs and AuNPs. The addition of leaves extract of $B$. tomentosa to the reaction medium induced a cathodic peak shift towards the negative potential, resulting in the reduction of silver and gold ions to AgNPs and AuNPs respectively. This implied that the leaves extract stabilized the nanoparticles. Cyclic voltammogram

Table 4. Percentage (\%) viability of Vero cells treated with AgNP, AuNP and aqueous extract of leaves at different concentrations.

\begin{tabular}{lccc}
\hline & \multicolumn{3}{c}{ Vero cells } \\
\cline { 2 - 4 } & $\begin{array}{c}\text { Cells treated } \\
\text { (ith AgNP }\end{array}$ & $\begin{array}{c}\text { Cells treated } \\
\text { with AuNP } \\
(\% \text { viability })\end{array}$ & $\begin{array}{c}\text { Cells treated } \\
\text { with aqueous } \\
\text { extract of leaves } \\
(\% \text { viability })\end{array}$ \\
\hline 1000 & 27.4 & 23.6 & 43.9 \\
500 & 44.3 & 39.9 & 54.2 \\
250 & 59.7 & 47.4 & 63.3 \\
125 & 65.7 & 56.3 & 71.4 \\
62.5 & 71.3 & 64.3 & 77.2 \\
31.2 & 79.2 & 72.9 & 84.7 \\
15.6 & 85.6 & 79.1 & 89.9 \\
7.8 & 93.2 & 86.8 & 95.2 \\
Control & 100 & 100 & 100 \\
\hline
\end{tabular}

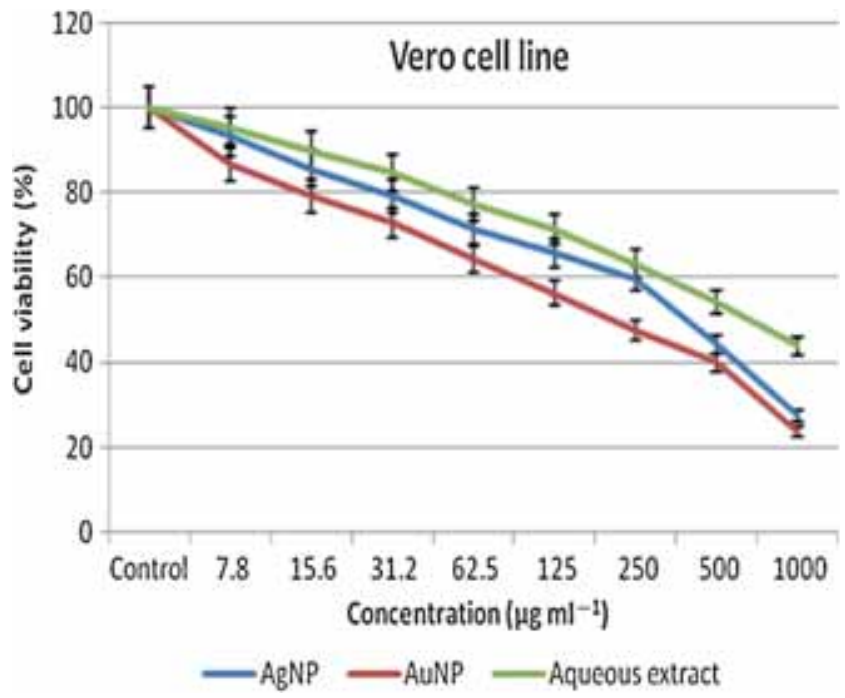

Figure 9. Comparative biocompatible efficacy of AgNP, AuNP and aqueous extract of leaves on Vero cells. 
Table 5. Percentage (\%) viability of A-549, HEp-2 and MCF-7cells treated with AgNP, AuNP and aqueous extract of leaves at different concentrations.

\begin{tabular}{|c|c|c|c|c|c|c|c|c|c|}
\hline \multirow[b]{2}{*}{$\begin{array}{l}\text { Concentration } \\
\left(\mu \mathrm{g} \mathrm{ml}^{-1}\right)\end{array}$} & \multicolumn{3}{|c|}{ A-549 cells } & \multicolumn{3}{|c|}{ HEp-2 cells } & \multicolumn{3}{|c|}{ MCF-7 cells } \\
\hline & $\begin{array}{c}\text { Cells } \\
\text { treated } \\
\text { with } \\
\text { AgNP } \\
(\% \\
\text { viability) }\end{array}$ & $\begin{array}{c}\text { Cells } \\
\text { treated } \\
\text { with } \\
\text { AuNP } \\
(\% \\
\text { viability) }\end{array}$ & $\begin{array}{c}\text { Cells } \\
\text { treated } \\
\text { with aqueous } \\
\text { extract } \\
\text { of leaves } \\
\text { (\% viability) }\end{array}$ & $\begin{array}{c}\text { Cells } \\
\text { treated } \\
\text { with } \\
\text { AgNP } \\
(\% \\
\text { viability) }\end{array}$ & $\begin{array}{c}\text { Cells } \\
\text { treated } \\
\text { with } \\
\text { AuNP } \\
(\% \\
\text { viability) }\end{array}$ & $\begin{array}{c}\text { Cells } \\
\text { treated } \\
\text { with aqueous } \\
\text { extract of } \\
\text { leaves } \\
\text { (\% viability) }\end{array}$ & $\begin{array}{c}\text { Cells } \\
\text { treated } \\
\text { with } \\
\text { AgNP } \\
(\% \\
\text { viability) }\end{array}$ & $\begin{array}{c}\text { Cells } \\
\text { treated } \\
\text { with } \\
\text { AuNP } \\
(\% \\
\text { viability) }\end{array}$ & $\begin{array}{c}\text { Cells } \\
\text { treated } \\
\text { aqueous } \\
\text { with extract } \\
\text { of leaves } \\
\text { (\% viability) }\end{array}$ \\
\hline 1000 & 10.4 & 11.3 & 8.6 & 13.2 & 6.61 & 10.7 & 11.1 & 4.3 & 0.0 \\
\hline 500 & 16.5 & 14.7 & 12.1 & 16.5 & 13.2 & 18.1 & 14.5 & 7.7 & 3.2 \\
\hline 250 & 22.6 & 27.8 & 21.7 & 30.5 & 17.3 & 27.2 & 18.8 & 12.8 & 7.5 \\
\hline 125 & 27.8 & 34.7 & 40 & 42.1 & 28.0 & 34.7 & 31.6 & 21.3 & 13.9 \\
\hline 62.5 & 36.5 & 47.8 & 46 & 65.2 & 40.4 & 46.2 & 49.5 & 26.4 & 22.5 \\
\hline 31.2 & 48.6 & 53.0 & 57.3 & 72.7 & 51.2 & 63.6 & 70.9 & 41.8 & 35.4 \\
\hline 15.6 & 60.0 & 64.3 & 73 & 80.1 & 66.1 & 70.2 & 84.6 & 58.1 & 44.0 \\
\hline 7.8 & 70.4 & 77.3 & 82.6 & 90.0 & 78.5 & 80.1 & 98.2 & 64.1 & 63.4 \\
\hline Control & 100 & 100 & 100 & 100 & 100 & 100 & 100 & 100 & 100 \\
\hline
\end{tabular}

of AgNPs showed peaks at -0.23 and $0.52 \mathrm{~V}$, while AuNPs showed peaks at -1.19 and $0.95 \mathrm{~V}$. Similarly, references [38] and [39] reported cyclic voltammetric analysis of silver and gold nanoparticles using Morinda tinctoria fruit and Couroupita guianensis flower extract, respectively.

\section{In vitro anticancer activity of silver, gold nanoparticles and aqueous extract of leaves on Vero, A-549, HEp-2 and MCF-7 cells}

The $\mathrm{IC}_{50}$ values of Vero, A-549, HEp-2 and MCF-7 cells treated with silver, gold nanoparticles, aqueous extract of leaves of $B$. tomentos $a$ and their anticancer efficacy are depicted in table 3 . The percentage $(\%)$ viability of Vero cells treated with AgNP, AuNP and aqueous extract of leaves at different concentrations are shown in table 4. Figure 9 depicts the comparative biocompatible efficacy of AgNP, AuNP and aqueous extract of leaves on Vero cells. From the figure, the $\mathrm{IC}_{50}$ values of AgNPs, AuNPs and aqueous extract of leaves were determined to be 425.0, 212.5 and $700.0 \mu \mathrm{g} \mathrm{ml}^{-1}$, respectively. The values indicate that AgNPs, AuNPs and aqueous extract of leaves exhibited cytotoxicity only at very high concentrations and were found to be biocompatible. Table 5 shows the percentage (\%) viability of A-549, HEp2 and MCF-7 cells treated with AgNP, AuNP and aqueous extract of leaves at different concentrations. The table indicated that both silver and gold nanoparticles as well as aqueous extract inhibited the proliferation of A-549, HEp-2 and MCF-7 cells in a dose- and time-dependent manner.

Figure 10 depicts comparative in vitro anticancer efficacy of AgNPs, AuNPs and aqueous extract of leaves on lung A-549 adenocarcinoma epithelial cells. From the figure, the $\mathrm{IC}_{50}$ of AgNPs, AuNPs and aqueous extract of leaves were determined to be $28.125,46.875$ and $50.0 \mu \mathrm{g} \mathrm{ml}^{-1}$, respectively. The values indicate that AgNPs exhibit higher cytotoxicity against A-549 cells at very low concentrations

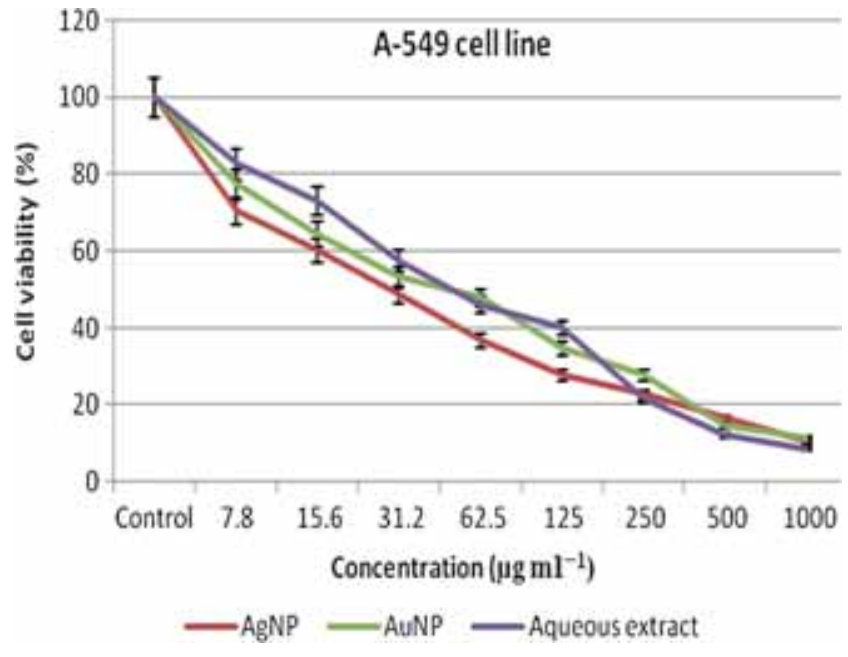

Figure 10. Comparative anticancer efficacy of AgNP, AuNP and aqueous extract of leaves against A-549 cells.

compared with AuNPs and aqueous extract of leaves. Niranjana et al [40] and Sathishkumar et al [41] reported in vitro anticancer activity of AgNPs and AuNPs against A-549 cells using Cardiospermum halicacabum and Illicium verum, respectively. Figure 11a shows the microscopic images of control A-549 cells, which were healthy, polygonal and adherent to the well plate. Figure $11 \mathrm{~b}$ and c presents microscopic images of A-549 cells treated with AgNP at $28.125 \mu \mathrm{g} \mathrm{ml}^{-1}$ and AuNP at $46.875 \mu \mathrm{g} \mathrm{ml}^{-1}$.

Figure 12 shows comparative in vitro anticancer activity of AgNPs, AuNPs and aqueous extract of leaves against laryngeal HEp-2 carcinoma epithelial cells. The $\mathrm{IC}_{50}$ values of $103.125,34.375$ and $53.125 \mu \mathrm{g} \mathrm{ml}^{-1}$ were determined from the figure graphically. The values indicate that AuNPs exhibited higher cytotoxicity against HEp-2 cells at very low concentrations compared with aqueous extract of leaves and AgNPs. The in vitro anticancer activity of AgNPs and 
AuNPs against HEp-2 cells has been reported using Phyllanthus emblica and endophytic fungi by Rosarin et al [42] and Nachiyar et al [43], respectively. Control cells of HEp2 were found to be healthy, elongated, grouped together to
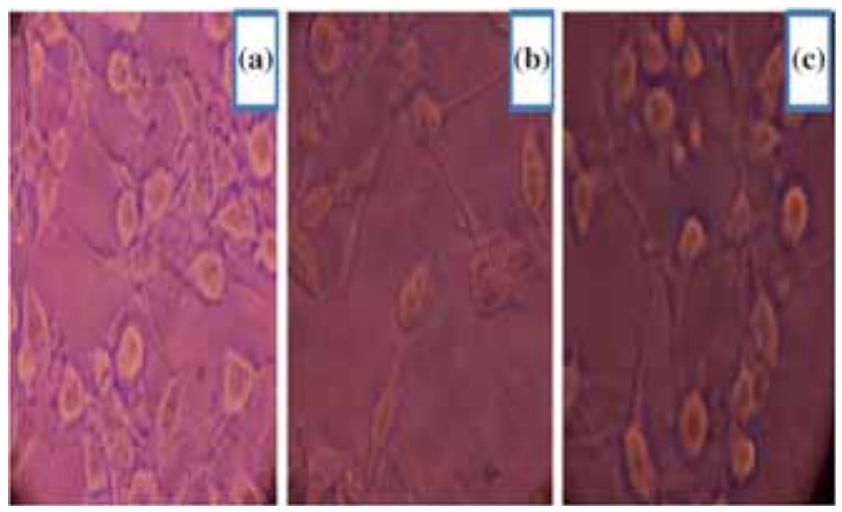

Figure 11. (a) Control A-549 cells, (b) AgNP $28.125 \mu \mathrm{g} \mathrm{ml}^{-1}$ and (c) AuNP $46.875 \mu \mathrm{g} \mathrm{ml}^{-1}$.

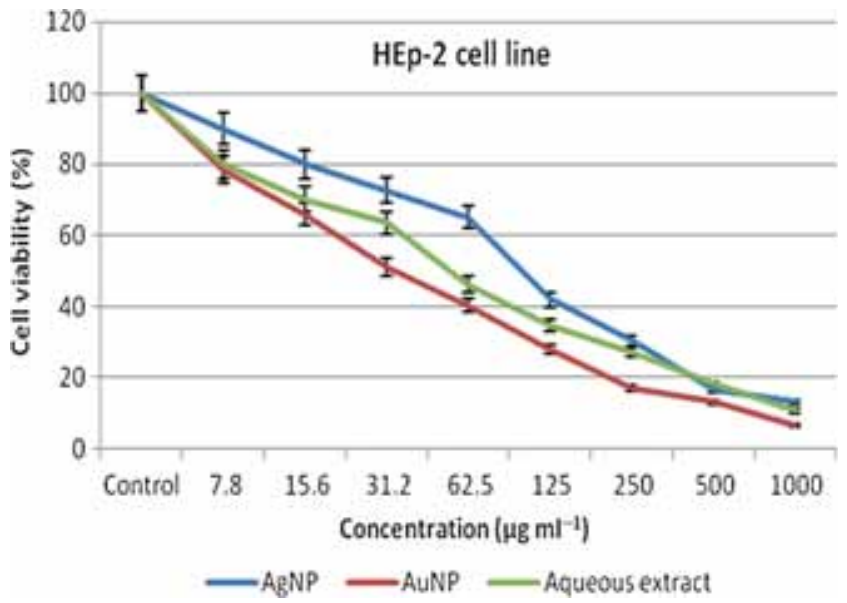

Figure 12. Comparative anticancer efficacy of AgNP, AuNP and aqueous extract of leaves against HEp-2 cells.
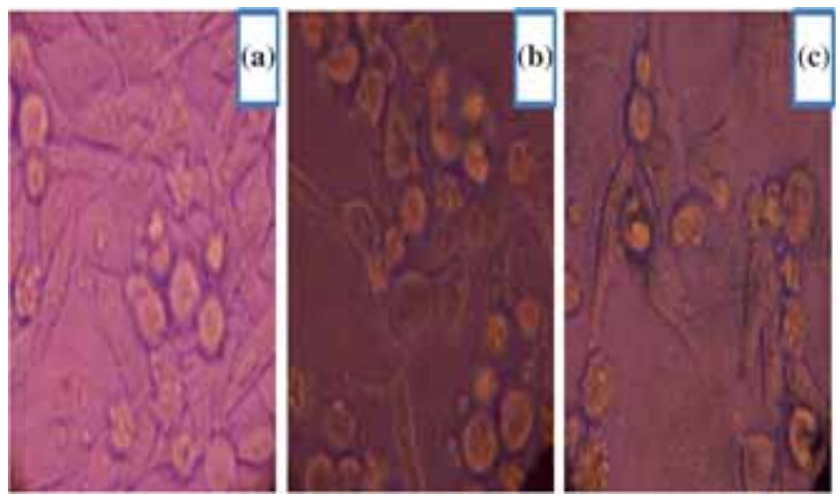

Figure 13. (a) Control HEp-2 cells, (b) AgNP $103.125 \mu \mathrm{g} \mathrm{ml}^{-1}$ and (c) AuNP $34.375 \mu \mathrm{g} \mathrm{ml}^{-1}$. form colonies and smoothly attached to the well plate as shown in figure 13a. Figure 13b and c depicts microscopic images of HEp- 2 cells treated with AgNP at $103.125 \mu \mathrm{g} \mathrm{ml}^{-1}$ and AuNP at $34.375 \mu \mathrm{g} \mathrm{ml}^{-1}$.

Comparative in vitro anticancer efficacy of AgNPs, AuNPs and aqueous extract of leaves against human breast MCF-7 adenocarcinoma cells is shown in figure 14. From the figure, the $\mathrm{IC}_{50}$ values of $62.5,23.4$ and $13.26 \mu \mathrm{g} \mathrm{ml}^{-1}$ were determined graphically. The values show that aqueous extract of leaves of B. tomentosa exhibited higher anticancer activity against MCF-7 cells at very low concentrations compared with AuNPs and AgNPs. Similarly, references [44] and [45] reported in vitro anticancer activity of AgNPs and AuNPs against MCF-7 cells using Spirulina platensis and eight different green extracts of plants, respectively. Control cells of MCF-7 were found to be polyhydric or stellate showing slender lamellar expansions that joined neighbouring cells as seen in figure 15a. Figure 15b presents MCF-7 cells treated with $\mathrm{AgNP}$ at a concentration $62.5 \mu \mathrm{g} \mathrm{ml}^{-1}$ and figure $15 \mathrm{c}$ depicts MCF-7 cells treated with AuNP at $23.4 \mu \mathrm{g} \mathrm{ml}^{-1}$.

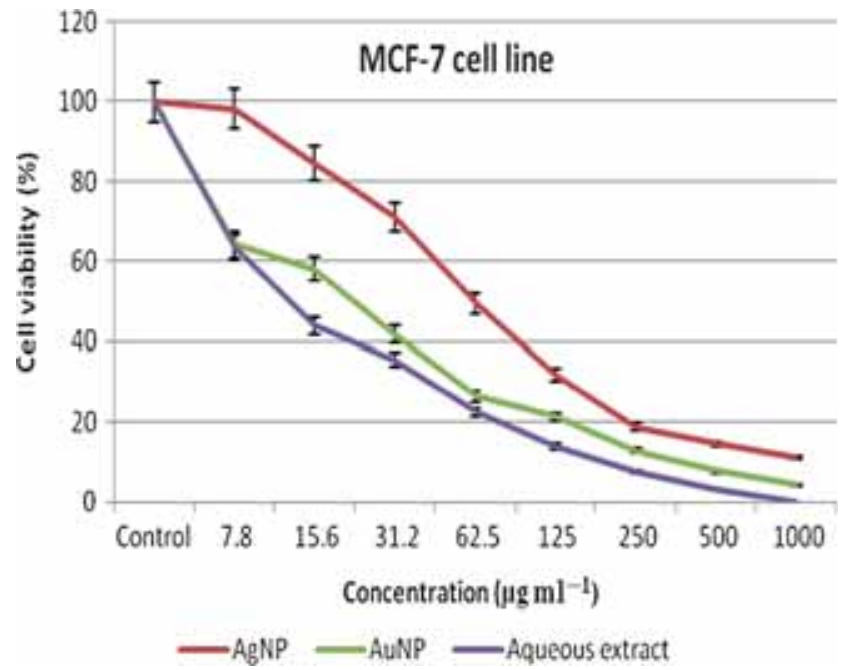

Figure 14. Comparative anticancer efficacy of AgNP, AuNP and aqueous extract of leaves against MCF-7 cells.
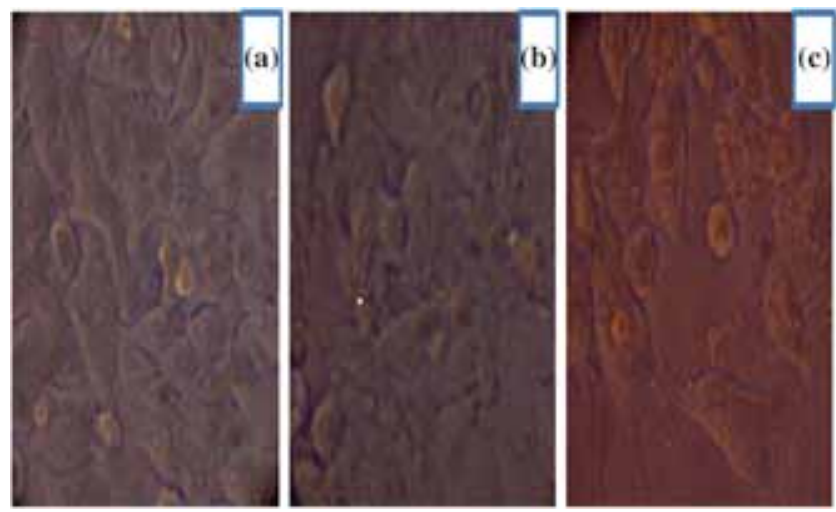

Figure 15. (a) Control MCF-7 cells, (b) AgNP $62.5 \mu \mathrm{g} \mathrm{ml}^{-1}$ and (c) AuNP $23.4 \mu \mathrm{g} \mathrm{ml}^{-1}$. 
Microscopic images of A-549, HEp-2 and MCF-7 reveal that cells treated with AgNP and AuNP induced apoptosis or programmed cell death, which is evident from the above figures. The characteristic morphological changes of the three cancer cells treated with AgNP and AuNP were spherical cells, cells detached from the culture or well plate, cell shrinkage, membrane blebbing, cytoplasmic condensation, bubbling and production of numerous cell surface protuberances at the plasma membrane. Similar changes in morphology of A-549, HEp-2 and MCF-7 cells have been reported by $[46,47]$ and [48], respectively.

\section{Conclusion}

A simple, cost-effective synthesis of non-toxic silver and gold nanoparticles has been performed using aqueous extract of leaves of B. tomentosa Linn and their spectroscopic, morphological, chemical, structural, thermal, electrochemical characterization and in vitro anticancer efficacy on A-549, HEp-2 and MCF-7 cells have been studied and compared. The presence of phytoconstituents such as proteins, phenols, tannins and flavonoids in the aqueous extract might be responsible for the synthesis of AgNP and AuNP. MTT assay confirmed that both AgNPs and AuNPs as well as aqueous extract of leaves inhibited the proliferation of A-549, HEp-2 and MCF-7 cells in a dose- and time-dependent manner, thus confirming the high anticancer efficiency of the nanoparticles at low concentrations.

The green synthesized silver and gold nanoparticles were found to be stable and the key ingredients responsible for reduction should be isolated and quantified. Further, this study suggests that both silver and gold nanoparticles synthesized using aqueous leaves extract can be used as a potential agent in cancer therapy. Yet, the mechanism of action and specific activity of synthesized silver and gold nanoparticles and aqueous extract of leaves against different cancer cells need to be thoroughly investigated.

\section{Acknowledgement}

We are thankful to the Department of Chemistry, B S Abdur Rahman University, Chennai, The Director, NCNSNT, University of Madras, Chennai, and Royal Bio Research Centre, Chennai, for providing necessary facilities to complete the present study.

\section{Conflict of Interest}

The authors declare that they have no conflict of interest.

\section{References}

[1] Faraday M 1857 Philos. Trans. R. Soc. Lond. 147145

[2] Schoen G and Simon U 1995 Colloid Polym. Sci. 273202

[3] Montemerlo M S, Love J C, Opiteck G J, Goldhaber Gorden D and Eleenbogen J V 1996 MTRE corporation technical report
[4] Dirix Y, Bastioan C, Caseri W and Smith P 1999 Adv. Mater. 11223

[5] Wohctjen H and Snow A W 1998 Anal. Chem. 702856

[6] Storhoff J J, Elghanian R, Mucic R C, Mirkin C A and Letisinger R L 1998 J. Am. Chem. Soc. 1201959

[7] Mirkin C A, Letisinger R L, Mucic R C and Storhoff J J 1996 Nature 382607

[8] Elghanian R, Storhoff J J, Mucic R C, Letisinger R L and Mirkin C A 1997 Science 2771078

[9] Retchkiman-Schabes P S, Canizal G, Becerra-Herrera R, Zorrilla C, Liu H B and Ascencio J A 2006 Opt. Mater. 2995

[10] Gu H, Ho P L, Tong E, Wang L and Xu B 2003 Nano Lett. 3 1261

[11] Ahmad Z, Pandey R, Sharma S and Khuller G K 2005 Ind. J. Chest Dis. Allied Sci. 48171

[12] Gong P, Li H, He X, Wang K, Hu J and Tan W 2007 Nanotechnology 18604

[13] Frattini A, Pellegri N, Nicastro D and De Sanctis O 2005 Mater. Chem. Phys. 94148

[14] Everts M, Saini V, Leddon J L, Kok R J, Stoff-Khalili M, Preuss M A et al 2006 Nano Lett. 6587

[15] Paciotti G F, Kingston D G I and Tamarkin L 2006 Drug Dev. Res. 6747

[16] Narayanan K B and Sakthivel N 2010 Adv. Colloid Interf. Sci. 1561

[17] Sharma N C, Sahi S V, Nath S, Parsons J G, Gardea-Torresdey J L and Pal T 2007 Environ. Sci. Technol. 415137

[18] Mohanpuria P, Rana N K and Yadav S K 2008 J. Nanopart. Res. 10507

[19] Kumar V and Yadav S K 2009 J. Chem. Technol. Biotechnol. 84151

[20] Shankar S S, Ahmad A and Sastry M 2003 Biotechnol. Prog. 191627

[21] Li S, Shen Y, Xie A, Yu X, Qiu L, Zhang L et al 2007 Extract. Green Chem. 9852

[22] Shankar S S, Rai A, Ahmad A and Sastry M 2004 J. Colloid Interf. Sci. 275496

[23] Nadagouda M N and Varma R S 2008 Green Chem. 10859

[24] Ankamwar B, Damle C, Ahmad A and Sastry M 2005 J. Nanosci. Nanotechnol. 51665

[25] Song J Y and Kim B S 2009 Bioprocess Biosyst. Eng. 3279

[26] Rita Anusha Grace N, Santhi Swaroop M and Vijaya Lakshmi N 2014 Int. J. Univers. Pharm. Life Sci. 3296

[27] Mannangatti V, Ayyasamy B, Rangasamy M, Emin B and Natesan S K 2010 J. Global Pharma Technol. 271

[28] Rhama S and Madhavan S 2012 J. Drug Deliv. Therap. 276

[29] Mukundan D, Mohankumar R and Vasanthakumari R 2014 Int. J. Innovat. Res. Sci. Eng. 2375

[30] Mukundan D, Mohankumar R and Vasanthakumari R 2015 Mater. Today: Proc. 24309

[31] Saini J, Kashyap D, Batra B, Kumar S, Kumar R and Malik D K 2013 Indian J. Appl. Res. 3209

[32] Mosmann T 1983 J. Immunol. Methods 6555

[33] Singh A K, Talat M, Singh D P and Srivastava O N $2010 \mathrm{~J}$. Nanopart. Res. 121667

[34] Dinesh S, Karthikeyan S and Arumugam P 2012 Arch. Appl. Sci. Res. 4178

[35] Anuradha J, Abbasi T and Abbasi S A 2015 J. Adv. Res. 6711 
[36] Mittal A K, Kaler A and Banerjee U C 2012 Nano Biomed. Eng. 4118

[37] Ismail E H, Khalil M M H, Al Seif F A and El-Magdoub F 2014 Prog. Nanotechnol. Nanomater. 31

[38] Kirubha R and Alagumuthu G 2013 Asian J. Pharm. Clin. Res. 660

[39] Kirubha R and Alagumuthu G 2014 Int. J. Adv. Sci. Techn. Res. 4891

[40] Niranjana V A, Narendhar C and Anbarasan B 2012 Int. J. Drug Discov. Herb. Res. 2504

[41] Sathishkumar M, Pavagadhi S, Mahadevan A and Balasubramanian R 2015 Ecotoxicol. Environ. Saf. 114232

[42] Rosarin F S, Arulmozhi V, Nagarajan S and Mirunalini S 2013 Asian Pac. J. Trop. Med. 61
[43] Nachiyar V, Sunkar S, Prakash P and Bavanilatha M 2015 Der. Pharma. Chem. 731

[44] Rejeeth C, Nataraj B, Vivek R and Sakthivel M 2014 Med. Aromat. Plants 3163

[45] Kamala Priya M R and Iyer P R 2015 Appl. Nanosci. 5443

[46] Ho Y F, Karsani S A, Yong W K and Malek S N A 2013 Evid.-Based Complement. Alternat. Med. 2013 Article ID 857257,10

[47] Arulvasu C, Babu G, Manikandan R, Srinivasan P, Sellamuthu S, Prabhu D et al 2010 J. Pharm. Res. 31485

[48] Yadav S, Seer H and Murthy R R 2012 Int. J. Pharm. Res. Bio-Sci. 1160 